Website : http://dayamas.unmermadiun.ac.id/index.php/dayamas

\title{
Pembuatan Barcode Produk Industri Meubel dan Furniture untuk Mendukung Ekspor Produk Ber-Sertifikat Legalitas Kayu
}

\author{
Rahmanta Setiahadi ${ }^{1}$, Denies Priantinah $\mathrm{S}^{2}$, Djoko Setyo Martono ${ }^{3}$ \\ ${ }^{1,3}$ Fakultas Pertanian Universitas Merdeka Madiun; ${ }^{2}$ Fakultas Ekonomi Universitas Negeri Yogjakarta \\ Email: rahmanta_setiahadi@unmer-madiun.ac.id
}

\begin{abstract}
Timber Legality Certificate is to meet the requirements of the legality of timber for the forest industry. Application of timber legality verification system allows Indonesia opened wider timber market, especially European market, through the signing of the Voluntary Partnership Agreement (VPA) in September 2013. The forestry industry, timber legality certificate must fulfill in order to be able to do eskport product. Must to get the V-legal documents in any export activity forestry product timber legality certified consequences must be applied to production management system and marketing system. The research objective is to create a system of production information via barcode for small industries that already have a certificate of Timber Legality. The results showed that the ability to prepare the production and marketing of information systems to support the administration of $V$-legal documents in the export activities for small industries, a serious problem in meeting the document export goods. Therefore, barcode software development program to help solving the problems facing SMEs in the furniture industry and furniture administrating $V$ legal documents.
\end{abstract}

Keywords--: small industry, V-Legal, export, barcode

\section{PENDAHULUAN}

Kesepakatan FLEGT-VPA (Voluntary Partnership Agreement on Forest Law Enforcement Governance and Trade) antara Indonesia dengan Uni Eropa, bertujuan untuk menghentikan perdagangan kayu ilegal dan memastikan hanya kayu dan produk kayu yang telah diverifikasi legalitasnya yang boleh diimpor UE dari Indonesia. Indonesia adalah negara Asia pertama yang menandatangani FLEGT-VPA dengan UE, dan sejauh ini merupakan negara pengekspor kayu terbesar yang melakukan penanda-tanganan FLEGT-VPA.

Konsekuensi kesepakatan FLEGT-VPA berdampak pada perubahan kebijakan tata kelola sektor kehutanan dan tata kelola perdagangan industri kehutanan. Kebijakan SVLK untuk meningkatkan tata kelola kehutanan di Indonesia yang buruk. Di dunia international dikenal maraknya praktek illegal logging.

Peningkatan volume ekspor produk kehutanan yang menggunakan bahan baku legal, secara langsung akan berdampak pada peningkatan volume produksi pada industri kecil menengah yang menjadi supplier maupun pelaku ekspor secara langsung. Terlebih bagi IKM yang memiliki ijin ETPIK (Eksportir Terdaftar Produk Industri Kehutan-an). Terbukanya peluang pasar international, mendorong IKM untuk memperbaiki sistem manajemen pengelolaan produksi secara lebih tertib dan memiliki akuntabilitas yang tinggi. Salah satu teknologi yang bisa digunakan untuk membangun sistem tersebut adalah dengan penggunaan Barcode Produk.

Tujuan kegiatan pengabdian pada masyarakat ini untuk membuat sistem informasi produksi melalui barcode bagi IKM yang sudah memiliki S-LK (Sertifikat Legalitas Kayu). Sistem barcode produk ini akan memudahkan IKM dalam melakukan pemenuhan administrasi dokumen eskpor barang. 
Website : http://dayamas.unmermadiun.ac.id/index.php/dayamas

\section{KAJIAN LITERATUR}

Sistem informasi akuntansi memiliki peran yang penting dalam pengelolaan aktifitas dalam sebuah entitas. Peran sistem informasi akuntansi untuk meningkatkan kualitas dan mereduksi biaya produk atau jasa, meningkatkan efisiensi, meningkatkan kapabilitas pembuatan keputusan, peningkatan pengetahuan dalam bisnis. Dengan demikian sebuah sistem informasi akuntansi yang didisain dengan baik akan mampu meningkatkan efisiensi dan efektifitas dalam mendukung operasi perusahaan (Marshall B. Romney dkk, 2010)

Penggunaan barcode sebagai salah satu alat dalam sistem informasi akuntansi merupakan aplikasi transaksi berbasis scanner system. Penelitian menunjukkan bahwa perkembangan penggunakan data dengan menggunakan scanner system ini merupakan fitur yang menarik karena memberikan konektifitas antara internal perusahaan dengan pihak eksternal seperti konsumen dan supplier.

Scanner data yang dikombinasikan dengan data lain dalam perusahaan, aktitifas marketing, proses produksi dan lainnya akan membuka peluang bagi kemungkinan pengembangan model baru untuk merespon kebutuhan pasar dan kebutuhan informasi perusahaan. ( Steve Baron and Andrew Lock, 1995)

Barcode adalah kode yang terdiri atas kumpulan data optik berupa garis tipis dan tebal yang berisi informasi mengenai sebuah produk/ barang tertentu. Data-data yang tertuang pada barcode hanya bisa diketahui dengan menggunakan alat barcode scanner. Dari hasil scanning barcode akan diketahui data mengenai nama, merk, harga dan sebagainya (http://id.wikipedia.org/wiki/Kode_batang)

Penggunaan Barcode dalam pencatatan transaksi entitas bisnis merupakan salah satu aplikasi penggunaan teknologi informasi yang diharapkan akan memberikan kemudahan dalam pengelolaan bisnis seiring peningkatan akuntabilitas data keuangan yang dikelola perusahaan. Penelitian banyak menunjukkan bahwa penggunaan Teknologi Informasi akan memiliki dampak terhadap produktitifas. Teknologi informasi ini memiliki dampak positif terhadap input, proses produksi, output dan kualitas (Tridas Mukhopadhyay, Surendra Rajiv and Kannan Srinivasan, 1997)

\section{METODE}

Pengabdian pada masyarakat ini menggunakan metode pendampingan dan pelatihan. Ruang lingkup metode : 1) Sosialisasi rencana program untuk mengetahui tingkat persepsi calon mitra kerja; 2) Melakukan pengamatan alur pemenuhan dokumen eksport produk furniture dan meubel; 3) Merancang sistem informasi akutansi dan software barcode produk furniture dan meubel yang diekspor; 4) Pelatihan operasional implementasi sistem barcode produk secara berkelanjutan.

Lokasi kegiatan di UD Romansa Furniture Kabupaten Ngawi. Bahan dan alat yang digunakan antara lain : data bahan baku, catatan penggunaan bahan baku, catatan hasil produksi, dan catatan penjualan. Alat yang digunakan antara lain komputer, kamera, alat tulis dan sebagainya. Pelaksanaan kegiatan mulai bulan April sampai Desember 2015.

\section{HASIL DAN PEMBAHASAN}

Manufaktur, dalam arti yang paling luas, merupakan proses merubah bahan baku menjadi produk. Proses ini meliputi : perancangan produk, pemilihan material dan tahap-tahap proses dimana produk tersebut dibuat. Aktifitas manufaktur yang kompleks melibatkan berbagai variasi sumberdaya dan aktifitas perancangan produk, pembelian bahan baku, pemasaran, dan pengiriman. Untuk mendukung sistem manufaktur dibutuhkan sarana mesin dan perkakas sebagai kontrol produksi dan pelayanan konsumen. 
Website : http://dayamas.unmermadiun.ac.id/index.php/dayamas

Sistem informasi manufaktur dapat dirancang dengan sistem berbasis komputer dan berhubungan dengan sistem informasi fungsional lainnya. Sistem ini mendukung manajemen perusahaan dalam pemecahan masalah yang berhubungan dengan manufaktur produk perusahaan. Manufaktur bertumpu pada input, proses, dan output. Sistem ini digunakan untuk mendukung fungsi produksi yang meliputi seluruh kegiatan yang terkait dengan perencanaan dan pengendalian proses untuk memproduksi barang atau jasa.

Hasil pengamatan alur produksi pada UD Romansa Furniture dapat digambarkan sebagai berikut :

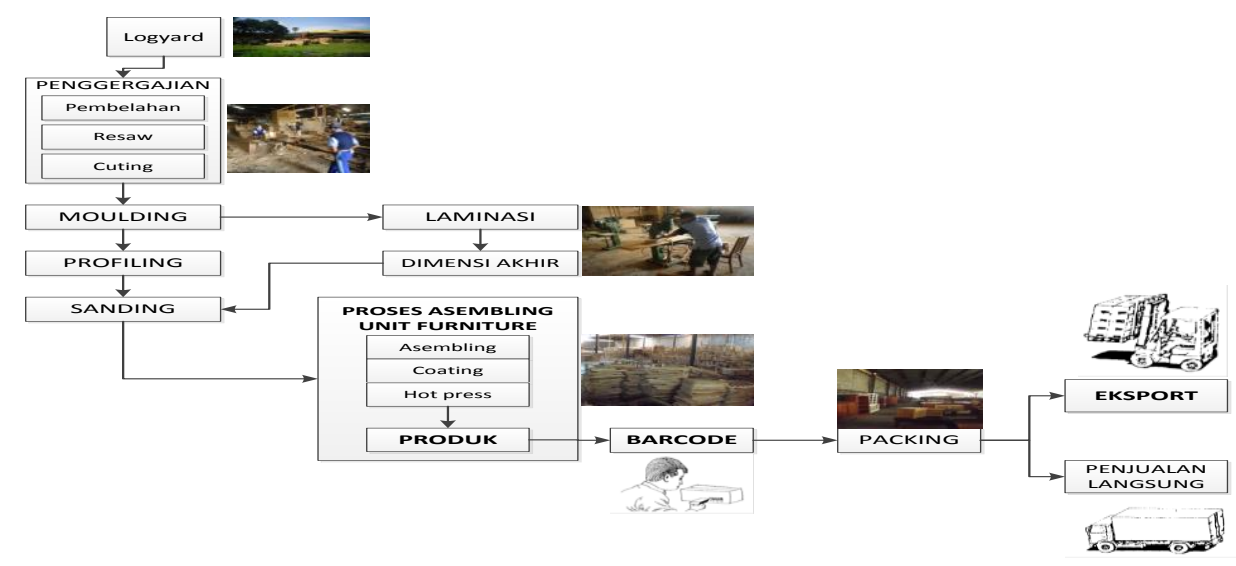

Gambar 1. Proses produksi UD Romansa.

Dengan melihat alur proses produksi tersebut, dibuat form tally sheet untuk mencatat alur pada setiap titik proses. Tally sheet yang diperlukan berupa : 1) Tally sheet pembelian kayu log; 2) Tally sheet kayu olahan; 3) Tally sheet penggunaan bahan baku dan produksi; 4) Tally sheet hasil produksi; dan 5) Tally sheet penjualan. Ke lima form tally sheet dikelompokkan dalam Sistem Transaksi. UD Romasa Furniture juga menggunakan produk setengah jadi yang diperoleh dari pemasok (supplier). Oleh karenanya, juga memerlukan tally sheet supplier.

Untuk mencatat semua aktifitas penjualan dan pemasaran, dibuat tally sheet berupa : 1) Tally sheet penjualan; 2) Tally sheet stock barang dan 3) Tally sheet data konsumen (customer). Semua data yang terekam dalam tally sheet digunakan untuk merancang sistem informasi manufaktur. Data-data yang sudah terekam akan menjadi dasar pembuatan desain barcode yang dibutuhkan. Desain pembuatan barcode, dirancang dengan mengikuti alur sebagai berikut :

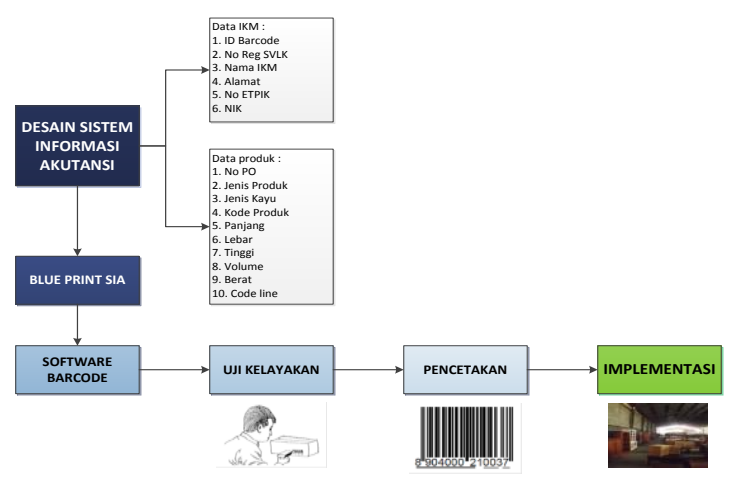

Gambar 2. Alur desain pembuatan barcode berdasar data tally sheet. 
Website : http://dayamas.unmermadiun.ac.id/index.php/dayamas

Siklus ini merupakan rangkaian aktivitas pemrosesan data terkait yang berkaitan dengan pembuatan barcode produk. Pada UD Romansa, proses ini meliputi seluruh proses yang terjadi sejak bahan baku sampai dengan output berupa hasil produk jadi yang dihasilkan.

Aktivitas disain barcode bertujuan untuk mendisain sebuah barcode produk yang memenuhi permintaan dalam hal informasi produk. Informasi ini menjelaskan proses produksi, asal usul bahan baku dan waktu produksi. Aktivitas ini diharapkan juga secara simultan meminimalkan biaya promosi. Menjaga keseimbangan informasi antara harga produk dengan kualitas produk diperlukan untuk mencapai tujuan kepuasan pelanggan.

Disain sistem informasi, terdiri dari : disain sub sistem Master, disain sub sistem Transaksi, disain sub sistem Laporan, dan disain sub sistem Setting. Masing-masing disain berisi informasi berbasis data yang dicatat pada tally sheet. Gambar disain sebagai berikut :

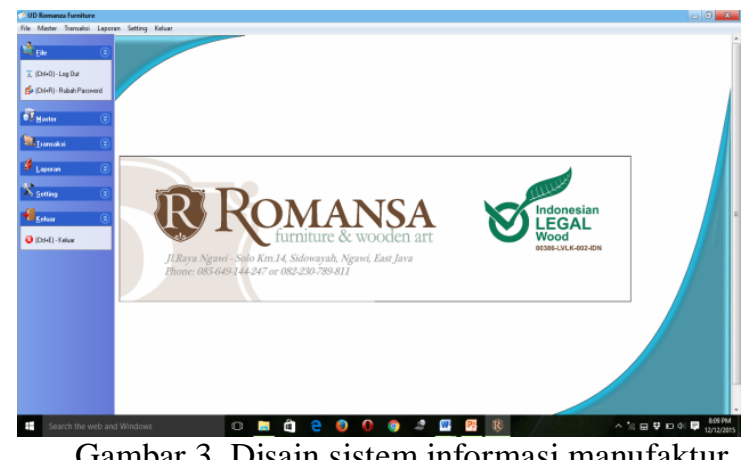

Secara umum, perusahaan manufaktur bertujuan untuk mencapai keuntungan dari hasil penjualan produknya. Oleh karena itu, sebuah sistem informasi tidak akan pernah terlepas unsur biaya yang terjadi di dalamnya. Di dalam sistem ini, perlu ditambahkan sub sistem biaya yang berfungsi untuk mengukur biaya yang terjadi selama proses produksi terjadi.

Tujuan sub sistem biaya untuk: (a) memberikan informasi perencanaan, pengendalian dan penilaian kinerja dari proses produksi; (b) memberikan data terkait dengan biaya yang akurat dan dapat diandalkan terkait dengan produk yang digunakan dalam menetapkan harga serta pengambilan keputusan terkait dengan bauran produk; (c) mengumpulkan dan memproses informasi yang dipergunakan dalam mengkalkulasi persediaan serta nilai Harga Pokok Penjualan (HPP).

Pada sub sistem laporan terdapat menu yang memudahkan pengisian dokumen eksport produk pada saat staffing maupun pengisian packing list dan dokumen PEB saat pemeriksaan di pelabuhan oleh Bea Cukai. Hal ini diperlukan bagi IKM yang melakukan eksport tanpa menggunakan jasa forwarding. Dengan fasilitas ini, pencetakan packing list secara otomatis sudah bisa disesuaikan dengan data customer maupun data penjualan. Data penjualan ini akan terkait dengan data produksi sesuai DO yang diterima dari buyer.

Setelah semua data sesuai antara DO dengan data customer, data produksi dan data penjualan, maka pencetakan barcode dapat dilakukan. Beberapa kodifikasi yang ada dalam barcode sudah memuat informasi-informasi yang diperlukan. Khususnya informasi yang diperlukan oleh pihak buyer di luar negeri. 
Website : http://dayamas.unmermadiun.ac.id/index.php/dayamas

Contoh kodifikasi barcode dicetak :

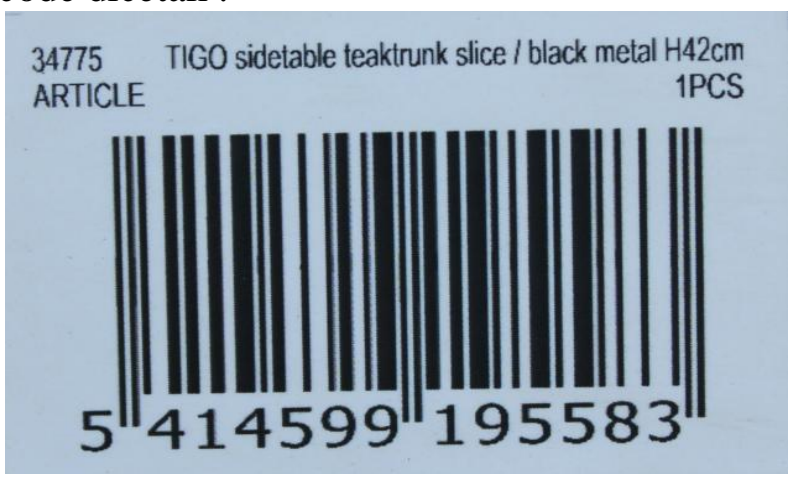

Gambar 4. Kodifikasi barcode produk.

Melalui kegiatan pendampingan IbM ini, dapat menumbuhkan kepercayaan diri bagi IKM dalam pengembangan usaha. Sekaligus memberi jaminan akan kualitas produk bagi para buyer di luar negeri yang berdampak pada peningkatan keuntungan. Sejak diberlakukannya SLK untuk eksport produk industri kehutanan, memberikan tren positif dan peluang bagi IKM. IKM seperti UD Romansa yang telah mendapatkan S-LK, memiliki kesempatan dan peluang untuk melakukan transaksi eksport dengan buyer di pasar international.

Kasus pengalaman UD Romansa, membuktikan bahwa peluang pasar akan terbuka jika pemenuhan standar produksi tercukupi. Analisa harga penjualan produk sebelum dan sesudah memiliki sertifikat legalitas kayu pada UD Romansa, disajikan pada tabel 1.

Berdasarkan tabel 1 dan tabel 2, terlihat bahwa kemampuan IKM seperti UD Romansa, mampu membuktikan bisa merebut pasar internasional. Kondisi ini memerlukan persyaratan yang mendukung. Persyaratan tersebut adalah: 1) Memiliki sertifikat S-LK; 2) Penataan sistem produksi; 3) Penataan sistem informasi manufaktur produk; 4) Mengikuti tren desain pasar internasional; dan 5) Melakukan pameran produk dengan mengikuti even-even pameran berskala internasional, seperti IFINA, IFEX dan lain lain.

Tabel 1. Analisa harga produk sebelum dan sesudah menerima S-LK.

\begin{tabular}{|c|c|c|c|}
\hline \multirow{2}{*}{$\begin{array}{c}\text { Jenis } \\
\text { Produk }\end{array}$} & \multicolumn{2}{|c|}{ Harga produk ( $\mathrm{Rp})$} & \multirow{2}{*}{ Buyer } \\
\hline & Sebelum & Sesudah & \\
\hline \multirow{6}{*}{$\begin{array}{l}\text { Tigo } \\
\text { sidetable }\end{array}$} & 125,000 & & Forwarder \\
\hline & & & Jogja dan \\
\hline & & & Pasuruan \\
\hline & & 810,000 & Belgia \\
\hline & & (60 \$ kurs & \\
\hline & & $13,500)$ & \\
\hline \multirow{6}{*}{$\begin{array}{l}\text { Teak } \\
\text { stump } \\
\text { on legs }\end{array}$} & 100,000 & & Forwarder \\
\hline & & & Jogja dan \\
\hline & & & Pasuruan \\
\hline & & 675,000 & USA \\
\hline & & $(50 \$$ kurs & \\
\hline & & $13,500)$ & \\
\hline
\end{tabular}


Website : http://dayamas.unmermadiun.ac.id/index.php/dayamas

Volume eksport produk Tigo Sidetable dan Teak stump on legs, yang dilakukan UD Romansa setelah mendapat S-LK, dalam kurun waktu 2014 -2015, disajikan pada tabel 2.

Tabel 2. Volume eksport UD Romansa dalam kurun waktu 2019-2020.

\begin{tabular}{llll}
\hline \multicolumn{1}{c}{$\begin{array}{c}\text { Jenis } \\
\text { Produk }\end{array}$} & $\begin{array}{l}\text { Tanggal } \\
\text { eskport }\end{array}$ & $\begin{array}{c}\text { Volume } \\
\text { eskport }\end{array}$ & $\begin{array}{c}\text { Negara } \\
\text { tujuan }\end{array}$ \\
\hline & $\begin{array}{l}\text { 14 Juni } \\
\text { 2019 }\end{array}$ & 20 feet & Belgia \\
\cline { 2 - 4 } $\begin{array}{l}\text { Tigo } \\
\text { sidetable }\end{array}$ & $\begin{array}{l}\text { Novem- } \\
\text { ber 2019 }\end{array}$ & & \\
\cline { 2 - 4 } & 50 feet & Belgia \\
& Oktober & & \\
& 2019 feet & Belgia \\
\hline Teak & 16 & 20 feet & Mississippi \\
stump & Agus- & & USA \\
on legs & tus 2020 & & \\
\hline \multicolumn{5}{c}{ Source: data primer, 2021. }
\end{tabular}

Kesimpulan kegiatan IbM ini adalah:

\section{KESIMPULAN}

1. Sertifikat Legalitas Kayu (S-LK) memberi peluang eksport dan berdampak positif pada margin keuntungan.

2. Sistem informasi manufaktur berdampak pada :

a. Memudahkan pengisian dokumen eksport produk pada saat staffing maupun pengisian packing list dan dokumen PEB saat pemeriksaan di pelabuhan oleh Bea Cukai.

b. Memberi jaminan akan kualitas produk bagi para buyer/konsumen di luar negeri yang berdampak pada peningkatan keuntungan.

c. Menumbuhkan kepercayaan diri untuk bagi pengusaha mengambil keputusan dalam pengembangan usaha selanjutnya.

\section{UCAPAN TERIMA KASIH}

Kegiatan IbM bagi IKM UD Romansa ini dapat berjalan lancar karena dukungan dana dari Direktorat Riset dan Pengabdian Masyarakat, Dirjen Riset dan Pengembangan tahun anggaran 2015. 
Website : http://dayamas.unmermadiun.ac.id/index.php/dayamas

\section{DAFTAR PUSTAKA}

Marshall B. Romney, Paul John Steinbart. 2010. Accounting Information Systems, 12th Edition. Prentice Hall Business Publishing.

Steve Baron and Andrew Lock. 1995. The Challenges of Scanner. Source: The Journal of the Operational Research Society, Vol. 46, No. 1 (Jan., 1995), pp. 50-61.

Sherry D. Ryan and David A. Harrison. 2000. Considering Social Subsystem Costs and Benefits in Information Technology Investment Decisions: A View from the Field on Anticipated Payoffs Author(s). Source: Journal of Management Information Systems, Vol. 16, No. 4, Impacts of InformationTechnology Investment on Organizational Performance (Spring, 2000), pp. 11-40.

http://id.wikipedia.org/wiki/Kode_batang

Tridas Mukhopadhyay, Surendra Rajiv and Kannan Srinivasan, 1997. Information Technology Impact on Process Output and Quality Author(s). Source: Management Science, Vol. 43, No. 12, Frontier Research on Information Systems and Economics (Dec., 1997), pp. 1645-1659. 